\title{
Growth Performance, Chemical Composition of Fillets, Liver and Intestinal Histology, and Expression of Lipid-Dependent Genes in Common Carp (Cyprinus carpio) Fed Artificial Diets
}

\author{
Eljasik Piotr ${ }^{1}$, Panicz Remigiusz $^{1 *(-)}$, Sobczak Małgorzata ${ }^{1}$, Sadowski Jacek ${ }^{2}$, \\ Ostaszewska Teresa ${ }^{3}$
}

\begin{abstract}
${ }^{1}$ West Pomeranian University of Technology, Faculty of Food Science and Fisheries, Department of Meat Science, 71550 Szczecin, 4 Kazimierza Królewicza Street, Poland

${ }^{2}$ West Pomeranian University of Technology, Faculty of Food Science and Fisheries, Department of Aquatic Bioengineering and Aquaculture, 71-550 Szczecin, 4 Kazimierza Królewicza Street, Poland

${ }^{3}$ Warsaw University of Life Sciences, Faculty of Animal Science, Laboratory of Ichthyobiology and Fishery, 02-786 Warsaw, 8 Ciszewskiego Street, Poland
\end{abstract}

\section{Article History}

Received 10 June 2020

Accepted 09 November 2020

First Online 11 November 2020

\section{Corresponding Author \\ Tel.: +48914496664 \\ E-mail: rpanicz@zut.edu.pl}

\author{
Keywords \\ $\beta$-oxidation \\ Cage culture \\ Commercial feed blends \\ Gene activity \\ Histomorphometry
}

\begin{abstract}
The study is a preface to redesign farming of carp, and the aim was to determine the influence of three artificial feeds on carp growth performance, chemical composition, intestinal and liver histology, and the expression of two main genes of fatty acid catabolism: acyl-coenzyme A oxidase 1 (acox1) and peroxisome proliferator-activated receptor $\alpha$ (ppar $\alpha$ ). The 61-days trials were run in set of 9 floating cages in triplicate $(n=3$ per diet). The results showed that zootechnical parameters (i.e. feed conversion ratio, protein efficiency ratio) significantly improved with increased level of fat in diet, for instance, the lowest FCR was noted for fish fed diet A $(9.90 \pm 0.23 \%$ of fat). Additionally, gene expression analysis revealed that activity of acox 1 and ppar $\alpha$ in the liver depend on the fat level in carp diet. The expression of ppar $\alpha$ and its target gene acox 1 in the intestine of fish showed a distinct pattern in relation to liver samples, since feeds with high and low levels of fat exerted a comparable effect on the mRNA level of the studied genes. In conclusion, this study showed that the level of fat in common carp diets correlated with the level of lipids in the meat.
\end{abstract}

\section{Introduction}

Considering the fact that climate change will negatively affect marine fisheries and aquaculture in the coming years, it is expected that culture of warm- and freshwater fish species may increase in size. In freshwater aquaculture, common carp (Cyprinus carpio) is regarded as one of the principal species, and production accounts for around $10 \%$ of global annual freshwater aquaculture (FAO, 2018). Moreover, common carp, due to its genetic and phenotypic plasticity (Xu et al., 2014), appears to be a highly promising aquaculture species, since the production volume and meat quality can be increased and adjusted in the coming years. Although, carp is recognized as ecofriendly fish, due to omnivorous benthic-feeding behaviour, modern approach is needed to unlock hidden potential in freshwater aquaculture and further reduce impact on environment (Aubin et al., 2019). To ensure eco-intensive carp farming traditional earth ponds should be combined with other production system (i.e. cage culture or recirculating aquaculture systems), and improved farming conditions (i.e. carefully designed feeds) should be implemented. Recently, significant effort has been made in aquaculture world to investigate more sustainable and shifted towards circular economy feeds (Kiron et al. 2012, Król et al., 2016, Panicz et al., 2017, Turchini et al., 2018). However, every modification of the feed composition affects the physiology of fish, e.g., its growth and performance, digestive tract and muscle histology, meat quality, as well as expression of diet- 
related genes. Furthermore, combining reduced wild stock components and quality improvement is either demanding or unachievable, since negative influence was often reported, particularly reduction of omega-3 long chain polyunsaturated fatty acids (Lazzarotto et al. 2018, Turchini et al., 2018). Hamilton et al. (2020) reported omega-3 fatty acids supply gap, which may widen because of fish reduced nutritional value. The encouraging solution could be utilisation of finishing feed blends, which will boost quality by improving fatty acid profile, reduce or stop widening omega-3 supply gap and save valuable and shrinking natural resources used in production of feed. Moreover, along with development of sustainable feeds, research providing guidance for fish farmers should be carried to augment ecological awareness throughout the world. Considering the influence of fish blends on fish performance, the eco-intensification of aquaculture should be balanced in terms of feed and fish well-being, but at the same time should provide a high-quality product in terms of nutritional and sensory values.

It is pertinent to note that results showing the effects of new commercial feed blends on common carp growth, performance, health and nutritional value are still scarce. Therefore, the aim of this study was to assess i) the zootechnical performance, ii) the intestine and liver histomorphology, iii) and gene expression of the acyl-coenzyme A oxidase 1 (acox 1 ) and peroxisome proliferator-activated receptor $\alpha$ (ppar $\alpha$ ) genes in cagecultured common carp fed three artificial diets. The presented study is a preface to redesign farming of carp by eco-intensification. Thus, results would be useful for the formulation of feeding criteria for maximized profit and reduced environmental impact.

\section{Materials and Methods}

\section{Fish, Nutrition Trial and Sampling}

Ethical guidance was obtained from the ethical committee of the Faculty of Food Sciences and Fisheries (ZUT in Szczecin, Poland). We followed the "Guidelines for the treatment of animals in behavioural research and teaching" published in Animal Behaviour (Anon, 2012).

The 61-day (May-July 2017) fish trials were performed at the Fisheries Research Station (FRS), Nowe

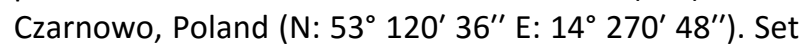
of 9 floating cages (net volume $3 \mathrm{~m}^{3}$ each; mesh size 3 $\mathrm{mm}$ ) submerged in cooling water discharged from the Dolna Odra Power Plant were used to run trials in triplicate ( $n=3$ per diet). One week prior to the start of the experiment 900 fish (fed natural diet) with a mean initial body weight of $427 \pm 10 \mathrm{~g}$ were selected from a pond farm located in Maliniec (NW Poland), transported to the FRS facility and randomly distributed in cages for acclimatization (100 fish/cage). During the experiment, the temperature of water ranged between $18^{\circ} \mathrm{C}$ and $28^{\circ} \mathrm{C}$. The fish were fed three commercially available, typical carp feeds: A - ALLER CLASSIC, $6 \mathrm{~mm}$ (Aller Aqua,
Denmark); B - EXTRACARP30, $6 \mathrm{~mm}$ (UAB Naujasis Nevėžis, Lithuania); C - SYTYKARP 33, 6 mm (PHU MAN Jan Hofman, Poland). Feeds A and B were manufactured via the extrusion process (pellet), while feed $C$ was made in the conventional process (textured feed).

Feeding was conducted by hand three times a day (at 10:00, 14:00 and 18:00 hours, in equal portions) until apparent satiation. This ration was approx. $3 \%$ of live weight per day. Additionally, bottoms of cages were checked daily to avoid feed retention. At 7 time points (i.e. days $1,5,12,19,33,47,61$ ) of the trials, all carps from each cage ( $n=3$ per diet) were weighed, and total fish weight per treatment was divided by the number of individuals in the cage depending on natural mortality rates to assess mean fish weight. At the end of the experiment, 9 fish from each diet were randomly selected ( $n=3$ per cage, $n=9$ per diet), weighed using an electronic scale $( \pm 0.01 \mathrm{~g})$ and sacrificed using a lethal dose $(2 \mathrm{ml} / \mathrm{l})$ of an anaesthetic (2-phenoxyethanol). Thereafter, viscera, liver and fillets were weighed using an electronic scale $( \pm 0.01 \mathrm{~g})$. Liver and intestine samples were immediately collected and preserved in DNA/RNA Shield ${ }^{\mathrm{TM}}$ (Zymo Research, USA) and stored in $-80^{\circ} \mathrm{C}$ until RNA extraction. Additionally, liver samples (approx. 125 $\mathrm{mm}^{3}$ ) and purged with deionized water anterior segments of intestine (approx. $5 \mathrm{~mm}$ ) were collected for histomorphological assessment, placed in $5 \mathrm{ml}$ glass jars and covered with $10 \%$ buffered formalin solution for 5 hours at room temperature.

\section{Measuring Growth Indices}

To describe dietary effect of three feeds on common carp, the following fish performance parameters were calculated: total growth (TG), feed conversion ratio (FCR), specific growth rate (SGR), protein efficiency ratio (PER), viscerasomatic index (VSI), hepatosomatic index (HIS) and survival rate (SR) using the following formulas:

$$
\begin{gathered}
\text { TG }=\frac{\text { weight gain }(\mathrm{g})}{\text { initial body weight }(\mathrm{g})} \times 100 \\
\mathrm{FCR}=\frac{\text { feed consumed }(\mathrm{g})}{\text { weight gain }(\mathrm{g})} \\
\mathrm{SGR}=\left[\frac{(\text { Ln final weight }- \text { Ln initial weight })}{\text { rearing days }}\right] \times 100 \\
\text { PSI }=\frac{\text { viscera weight }(\mathrm{g})}{\text { body weight }(\mathrm{g})} \times 100 \\
\text { HSI }=\frac{\text { liver weight }(\mathrm{g})}{\text { body weight }(\mathrm{g})} \times 100 \\
\mathrm{SR}=\frac{\text { final number }}{\text { initial number }} \times 100
\end{gathered}
$$




\section{Proximate Composition of Fish Fillets and Feed}

Basic chemical composition of whole fillets $(266.09 \pm 37.28 \mathrm{~g}$ each) prepared as pooled homogenates ( $n=3$ per cage, $n=9$ per diet) was determined according to AOAC (2007) standard procedures, simultaneously three feeds samples (approx. 200g each) were analysed. Crude protein content was measured by determining nitrogen content $(\mathrm{N} \times 6.25)$ according to the Kjeldahl method using a Tecator Kjeltec 2100 distillation unit (FOSS Analytical Co., Denmark) and crude lipid content was determined gravimetrically after Soxhlet lipid extraction on a Tecator Soxtec System HT 1043 (FOSS Analytical Co., Denmark). Moisture contents were obtained after drying in an oven at $105^{\circ} \mathrm{C}$ for $24 \mathrm{hr}$, ash content was determined after incineration at $550^{\circ} \mathrm{C}$ for $6 \mathrm{hr}$.

\section{Intestinal and Liver Histology}

After fixation in $10 \%$ buffered formalin solution for 5 hours at room temperature, liver and intestinal samples were dehydrated in absolute ethanol, saturated in intermediate solutions (benzene, benzene: paraffin), embedded in paraffin blocks, trimmed, sectioned $(4 \pm 1 \mu \mathrm{m})$, mounted on slides, incubated at $37^{\circ} \mathrm{C}$ and stained with haematoxylin and eosin. Additionally, Alcian Blue dye (Yamada, 1970) was used to stain goblet cells in intestinal samples. Then, slides were secured with DPX balsam (Burck, 1975). Slides ( $n=2$ per organ) from 3 specimens for each diet ( $n=6$ per diet) were examined using a 100x magnification (Nikon Eclipse E600, USA) with the NIS-Elements Basic Research software (Nikon Instruments Europe B.V, Netherlands). Intestinal sections were analysed against fold length, number of goblet cells per fold and size of goblet cells, whereas slides with liver were screened for hepatocyte (C) and hepatocyte nucleus (N) areas (200 measurements/parameter). Additionally, the nucleus:cytoplasm ratio (N/C) of hepatocytes was calculated, and the significance of the observed differences was assessed for each parameter.

\section{Gene Expression Analysis}

In the laboratory of Department of Aquatic Bioengineering and Aquaculture (ZUT in Szczecin,
Poland), samples preserved in DNA/RNA Shield ${ }^{\mathrm{TM}}$ (Zymo Research, USA) were defrosted and homogenized in 750 $\mu$ l of Tri Reagent ${ }^{\circledR}$ (Zymo Research, USA) for 60 seconds using a Minilys ${ }^{\oplus}$ personal homogenizer (Bertin Corp., USA). Total RNA was extracted using the Direct-zol ${ }^{\mathrm{TM}}$ RNA MiniPrep kit (Zymo Research, USA), with DNase I treatment. Then, quality and quantity of the RNA isolates were assessed using a NanoDrop 2000 (Thermo Scientific, USA) spectrophotometer. The reverse transcription reaction was performed using the Reverse Transcription System kit (Promega, USA) according to manufacturer's instructions. Real-time PCR reaction was performed on a QuantStudio ${ }^{\mathrm{TM}} 3$ device (TermoFisher Scientific, USA) using the PowerUp ${ }^{\text {TM }}$ SYBR $^{\text {TM }}$ Green Master Mix (TermoFisher Scientific, USA), $0.3 \mu \mathrm{M}$ of each primer and $1 \mu \mathrm{l}$ of cDNA templates in the final volume of $10 \mu \mathrm{l}$. The reaction was conducted using initial 2 minutes activation at $50^{\circ} \mathrm{C}$ and 2 minutes at $95^{\circ} \mathrm{C}$, followed by 40 cycles of denaturation at $95^{\circ} \mathrm{C}$ for 1 second and annealing/extending at $60^{\circ} \mathrm{C}$ for 30 seconds. Melting curve analysis $\left(60-95^{\circ} \mathrm{C}\right)$ was conducted at the end of each PCR thermal profile to assess the specificity of amplification. The activity of two genes, acylcoenzyme A oxidase 1 (acox 1 ) and peroxisome proliferator-activated receptor $\alpha$ (ppar $\alpha$ ) was evaluated against the reference Ribosomal protein L8 ( $r p / 8)$ gene (Table 1). Relative gene expression ( $n=9$ per diet) was calculated using the GeneEx (MultiD Analyzes, Sweden) program.

\section{Statistical Analysis}

All data are shown as mean \pm standard deviation unless otherwise specified. All statistical analyses were performed using Statistica 13 software (StatSoft, USA). Differences between the average parameters for each group were determined using the Kruskal-Wallis test and Tukey's HSD post-hoc test. Differences were considered statistically significant at $\mathrm{P} \leq 0.05$.

\section{Results}

\section{Fish Growth and Performance}

During the nutritional trial no disease signs were seen, and only natural mortality occurred with no significant difference between diets $(P>0.05)$. The feeds

Table 1. Sequences of PCR primers for the detection of two target genes (acox1 and ppar $\alpha$ ) and reference gene ( $r p / 8$ ) in common carp by real-time PCR

\begin{tabular}{|c|c|c|c|c|}
\hline Gene symbol & Sequence $5^{\prime} \rightarrow>3{ }^{\prime}$ & $\mathrm{Tm}$ & Function & Reference \\
\hline \multirow{2}{*}{$\operatorname{acoxl}{ }^{1}$} & ACAGCACAGCAAGAGCAATG & $51.8^{\circ} \mathrm{C}$ & neroxisomal $\beta$ oxidation & \multirow{4}{*}{ Corcoran et al., 2015} \\
\hline & ACAGAGTGGACAGCCGTATC & $53.8^{\circ} \mathrm{C}$ & peroxisomal p oxidation & \\
\hline \multirow{2}{*}{ ppara ${ }^{2}$} & GGGAAAGAGCAGCACGAG & $52.6^{\circ} \mathrm{C}$ & \multirow{2}{*}{ lipid metabolism } & \\
\hline & GCGTGCTTTGGCTTTGTT & $48.0^{\circ} \mathrm{C}$ & & \\
\hline \multirow{2}{*}{ rplo 3} & CTCCGTCTTCAAAGCCCATGT & $54.4^{\circ} \mathrm{C}$ & \multirow{2}{*}{ ribosomal protein coding } & \multirow{2}{*}{ Bickley et al., 2009} \\
\hline & TCCTTCACGATCCCCTTGATG & $54.4^{\circ} \mathrm{C}$ & & \\
\hline
\end{tabular}


significantly $(P \leq 0.05)$ affected common carp growth (Figure 1), FCR, SGR and PER (Table 2). Diet A fish showed the highest TG $(125.93 \pm 5.87 \%)$ during the trial and mean final body weight (FBW) reached $980.82 \pm 47.65 \mathrm{~g}(\mathrm{FCR}=2.32 \pm 0.09)$. Diet $\mathrm{B}$ carps doubled their weight ( $T G=102.28 \pm 3.70 \%)$, while diet $C$ showed the lowest TG $(74.52 \pm 3.56 \%)$, FBW of both diets were $871.07 \pm 33.85 \mathrm{~g}$ and $758.99 \pm 27.53 \mathrm{~g}$, respectively. The FCR and $S G R$ in diets $B$ and $C$ were significantly $(P \leq 0.05)$ lower compared to diet $A$. Regardless of FBW no differences were found in VSI and HSI across all fish. Significant differences between the individual weight values in diet $A$ compared to diet $B$ and $C$ were observed after 33 days of the trial. Moreover, significant differences $(P \leq 0.05)$ in growth between diet $B$ and $C$ were observed after 47 days of feeding.

\section{Chemical Composition of Fish Fillets and Feed}

The chemical analysis revealed significant differences $(P \leq 0.05)$ in feeds and fish fillets composition
(Table 3). Crude protein level in all feeds was greater than $31 \%$, and in feed B exceeded $33 \%$. The most apparent differences were observed for crude fat content in feeds. The highest level of fat was found in feed A (9.90 $\pm 0.23 \%)$, intermediate in feed B $(6.54 \pm 0.01 \%)$, and the lowest in feed C $(4.98 \pm 0.04 \%)$. The content of fat in fillets followed the pattern identified for feed, i.e. diet A fish had the highest level $(11.15 \pm 0.57 \%)$, those of diet B had an intermediate level $(7.07 \pm 0.40 \%)$, and those of group $C$ had the lowest level (3.95 $\pm 1.83 \%)$. Other parameters of feed and fish fillets remained at a relatively comparable level.

\section{Histological Analysis}

Histomorphological analysis showed significant differences $(P \leq 0.05)$ in the assessed parameters of the anterior segments of fish intestines and the size of hepatocyte nuclei (Table 4). The shortest folds were observed in the diet $C$ intestines, while no difference between diet $A$ and $B$ were found. The number of goblet

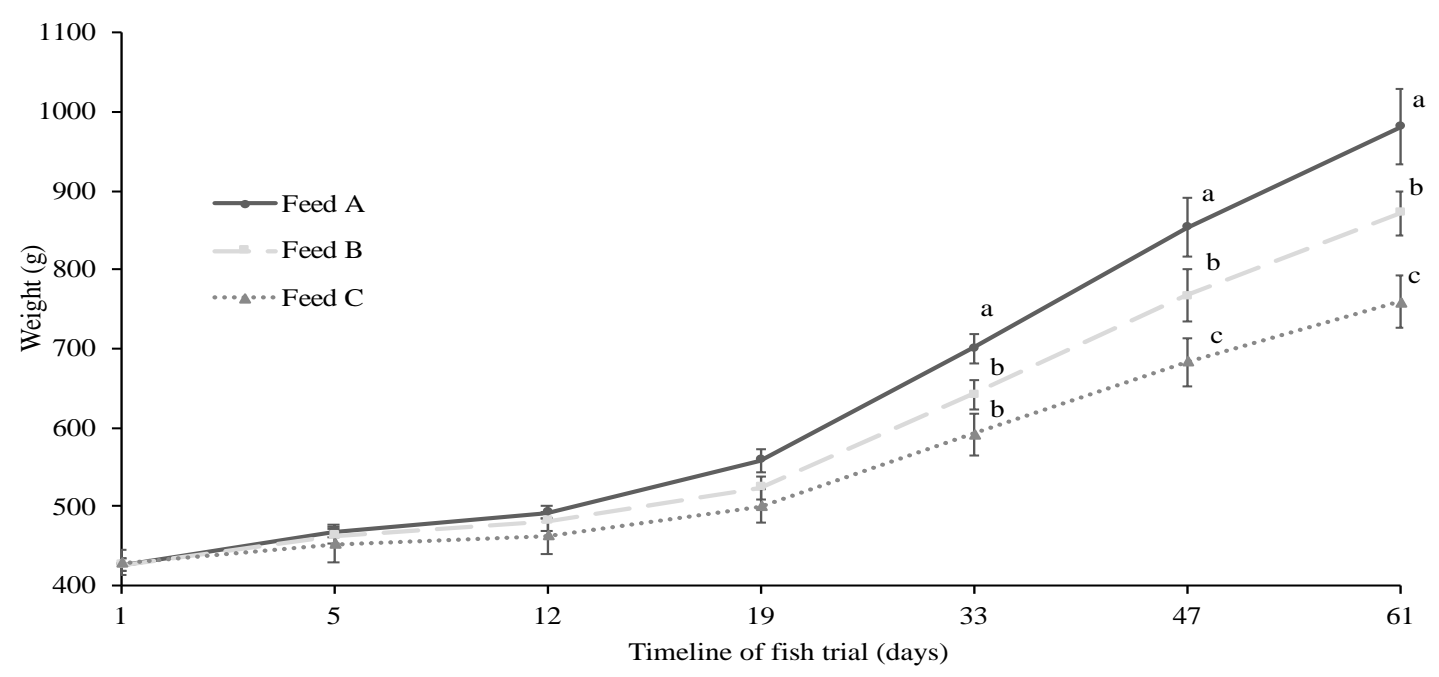

Figure 1. Average fish weight gains across 61 days long feeding trial of common carp in cage culture. Mean values ( $n=3$ replicates per diet) and standard deviation are presented in each weighing day. Mean values with various superscript letters in the same weighing day were found significantly different $(P \leq 0.05)$.

Table 2. Growth performance parameters of carps fed with the three experimental diets

\begin{tabular}{lccc}
\hline & $\mathrm{A}$ & $\mathrm{B}$ & $\mathrm{C}$ \\
\hline $\mathrm{IBW}^{1}(\mathrm{~g})$ & $426.67 \pm 9.07$ & $426.33 \pm 16.26$ & $429.00 \pm 7.94$ \\
$\mathrm{FBW}^{2}(\mathrm{~g})$ & $980.82 \pm 47.65^{\mathrm{a}}$ & $871.07 \pm 33.85^{\mathrm{b}}$ & $758.99 \pm 27.53^{\mathrm{c}}$ \\
$\mathrm{TG}^{3}(\%)$ & $125.93 \pm 5.87^{\mathrm{a}}$ & $102.28 \pm 3.70^{\mathrm{b}}$ & $74.52 \pm 3.56^{\mathrm{c}}$ \\
$\mathrm{FCR}^{4}$ & $2.32 \pm 0.09^{\mathrm{a}}$ & $2.68 \pm 0.07^{\mathrm{b}}$ & $3.40 \pm 0.16^{\mathrm{c}}$ \\
$\mathrm{SGR}^{5}(\% / \mathrm{d})$ & $1.36 \pm 0.07^{\mathrm{a}}$ & $1.17 \pm 0.04^{\mathrm{b}}$ & $0.93 \pm 0.05^{\mathrm{c}}$ \\
$\mathrm{PER}^{6}(\mathrm{~g} / \mathrm{g})$ & $1.34 \pm 0.04^{\mathrm{a}}$ & $1.16 \pm 0.03^{\mathrm{b}}$ & $0.91 \pm 0.04^{\mathrm{c}}$ \\
$\mathrm{VSI}^{7}(\%)^{*}$ & $16.09 \pm 4.49$ & $15.52 \pm 5.01$ & $14.33 \pm 3.27$ \\
$\mathrm{HSI}^{8}(\%)^{*}$ & $2.84 \pm 0.55$ & $2.80 \pm 0.78$ & $2.31 \pm 0.32$ \\
$\mathrm{SR}^{9}(\%)$ & $99.00 \pm 1.00$ & $99.67 \pm 0.58$ & $98.67 \pm 1.15$ \\
\hline
\end{tabular}

Explanations: Results represent mean \pm standard deviation ( $n=3$ replicates per diet; ${ }^{*} n=9$ fish per diet). Values with different superscripts indicate significant differences ( $P \leq 0.05)$. 1 initial body weight; 2 final body weight; 3 total growth; 4 feed conversion ratio; 5 specific growth rate; 6 protein efficiency ratio; 7 viscerosomatic index; 8 hepatosomatic index; 9 survival rate. 
cells per fold was the lowest in diet A carps compared with the other diets, which did not differ between each other. All diets differed significantly $(P \leq 0.05)$ based on the goblet cell area, and this parameter was the highest in diet $C$ fish, while the lowest in diet A carps. The analysis of liver histology showed no significant differences $(P>0.05)$ between the diets in the $N / C$ value. The only difference in the histomorphology of the liver was observed for the nucleus area which was significantly $(P \leq 0.05)$ larger in diet $B$ fish compared with the other. During the analysis, a minor percentage of hepatocytes with peripherally located nucleus was found in all variants (Figure 2).

\section{Gene Expression Analysis}

The results of gene expression analysis showed that the activity of acox 1 decreased along with the level of fat in the diets and was the lowest in diet C (Figure 3). Additionally, the expression of ppar $\alpha$ was significantly increased in the liver of diet A fish compared with the other diets. The analysis also revealed that the activity of ppara in diet B was downregulated in comparison with the other diets. The activities of acox 1 and ppar $\alpha$ in the intestines of carps $A$ and $C$ were upregulated compared with those fed diet $B$ where both genes were significantly $(P \leq 0.05)$ downregulated (Figure 4).

\section{Discussion}

The high-fat diets are utilised in aquaculture, due to economically reasonable growth performance improvement. However, inadequate diet for specific species may negatively affect fish processors, because of increased lipid concentration in internal organs enlarged volume of by-products, which thus far are not utilised sustainably. The results of this study showed progressive improvement of fish zootechnical parameters with increasing level of fat in diets. The FCR, SGR and PER improvement with increased dietary fat was previously described for common carp fry (Manjappa et al., 2002) and blunt snout bream,

Table 3. Proximate composition of three tested feed blends and common carp fed three diets

\begin{tabular}{lccc}
\hline & $\mathrm{A}$ & $\mathrm{B}$ & $\mathrm{C}$ \\
\hline Feed & & & $31.18 \pm 0.06^{\mathrm{a}}$ \\
\hline Crude protein (\%) & $31.60 \pm 0.23^{\mathrm{a}}$ & $33.36 \pm 0.47^{\mathrm{b}}$ & $4.98 \pm 0.04^{\mathrm{c}}$ \\
Crude fat (\%) & $9.90 \pm 0.03^{\mathrm{a}}$ & $6.54 \pm 0.01^{\mathrm{b}}$ & $5.37 \pm 0.02^{\mathrm{c}}$ \\
Crude ash (\%) & $5.60 \pm 0.05^{\mathrm{a}}$ & $4.34 \pm 0.84^{\mathrm{b}}$ & $92.93 \pm 0.10^{\mathrm{b}}$ \\
Dry matter (\%) & $95.05 \pm 0.15^{\mathrm{a}}$ & $94.31 \pm 0.65^{\mathrm{a}}$ & $15.88 \pm 0.01^{\mathrm{c}}$ \\
\hline Energy value (MJ) & $17.19 \pm 0.02^{\mathrm{a}}$ & $16.60 \pm 0.03^{\mathrm{b}}$ & \\
\hline Fillets & & & $17.97 \pm 0.47^{\mathrm{b}}$ \\
\hline Crude protein (\%) & $16.51 \pm 0.51^{\mathrm{a}}$ & $16.85 \pm 1.04^{\mathrm{ab}}$ & $3.95 \pm 1.83^{\mathrm{c}}$ \\
Crude fat (\%) & $11.15 \pm 0.57^{\mathrm{a}}$ & $7.07 \pm 0.40^{\mathrm{b}}$ & $1.08 \pm 0.04^{\mathrm{b}}$ \\
Crude ash (\%) & $1.02 \pm 0.01^{\mathrm{a}}$ & $1.06 \pm 0.01^{\mathrm{b}}$ & $23.24 \pm 1.94^{\mathrm{b}}$ \\
\hline
\end{tabular}

Table 4. The histomorphometric analysis of liver and intestine of carps fed three diets

\begin{tabular}{lccc}
\hline & $\mathrm{A}$ & $\mathrm{B}$ & $\mathrm{C}$ \\
\hline Liver & & & 140.24 \\
\hline Hepatocyte area & 151.91 & 149.00 & $(136.79-143.69)$ \\
$\left(\mu \mathrm{m}^{2}\right)$ & $(148.45-155.38)$ & $(146.07-151.92)$ & 29.07 \\
Nucleus area & 29.80 & 36.76 & $(28.21-29.94)^{\mathrm{a}}$ \\
$\left(\mu \mathrm{m}^{2}\right)$ & $(29.03-30.58)^{\mathrm{a}}$ & $(35.75-37.76)^{\mathrm{b}}$ & 0.22 \\
$\mathrm{~N} / \mathrm{C}^{1}$ ratio & 0.20 & 0.25 & $(0.20-0.22)$ \\
\hline Intestine & $(0.20-0.21)$ & $(0.20-0.26)$ & 993.20 \\
\hline Length of intestinal folds & 1185.19 & & $(953.42-1032.98)^{\mathrm{b}}$ \\
$(\mu \mathrm{m})$ & $(1152.88-1217.51)^{\mathrm{a}}$ & $(1187.38-1249.92)^{\mathrm{a}}$ & 137 \\
Number of Goblet cells per & 106 & 128 & $(128.20-144.94)^{\mathrm{b}}$ \\
fold & $(98.20-113.50)^{\mathrm{a}}$ & $(118.56-138.02)^{\mathrm{b}}$ & 83.65 \\
Goblet cell area $\left(\mu \mathrm{m}^{2}\right)$ & 72.35 & 65.85 & $(79.92-87.38)^{\mathrm{c}}$
\end{tabular}

Explanations: Results represent mean value and confidential interval in parenthesis ( $\mathrm{n}=6$ fish per diet). Values with different superscripts in row indicate significant differences $(P \leq 0.05)$. N/C - Nucleus area $\left(\mu \mathrm{m}^{2}\right) /$ hepatocyte cytoplasm area $\left(\mu \mathrm{m}^{2}\right)$. 
Megalobrama amblycephala (Cao et al., 2018). Although Poleksić et al. (2014) revealed that positive effect on weight gain is limited to certain threshold, above which fish show inability to utilise lipids. Our results undoubtedly set optimal threshold for common carp at the highest fat amount (9.90\%), while previously it has been reported at $8 \%$ (Poleksić et al., 2014), 9.3\% (Muzaffar et al., 2012) and 6\% (Abbas, 2007). In contrast, Abasubong et al. (2018) showed no significant differences in the final weight of common carps or zootechnical indices when analysing the growth performance and lipid metabolism of juvenile carps on a high-fat diet. This observation may indicate that the quality and ratio between diet ingredients have a higher influence on the proximate composition of fish fillets than the level of feed ingredients itself. Therefore, an equal or lower level of protein in high-energy diets compared to a low-energy diet results in better protein utilisation, known as the protein-sparing effect (Steffens, 1996). The results of this study indicate that a sufficient level of protein (30-35\%), proposed by Steffens (1996) together with a high lipid content, significantly improves the growth performance of common carp. Additionally, assuming that all carps formed a homogenous group (genetic line, age), the obtained results suggest that the chemical composition of carp fillets was influenced exclusively by the diets. This effect was clearly visible in fillet fat content, which was a directly proportional reflection of fat content in feeds. Likewise, Cao et al. (2018) who studied blunt snout bream and found an increased concentration of fat in the muscle tissue and VSI with an enhanced amount of lipids in diet. However, those outcomes are partially in line with our results for common carp, as we noted an increase of fat in muscle but no changes in VSI. This may further confirm adequate protein/lipid ratio in all tested diets, thus accumulation in internal organs was not triggered. In contrast to previously reported for grass carp (Ctenopharyngodon Idella) and tilapia (Oreochromis niloticus $\times 0$. aureus) lipid accumulation in viscera when lipids were supplied in excess (Gao et al., 2011).

Histomorphometric screening is a widely accepted approach to assess the adaptive and pathological changes in the gastrointestinal tract of fish induced by various stimuli, including nutrition. Our study showed that the intensive mode of feeding, did not alter the structure of the liver of fish from any group. However, it is worth mentioning that in all analysed groups, the N/C ratios of hepatocytes $(0.20-0.25)$ were higher compared with the values previously reported for adult (0.09-0.14) and juvenile (0.092-0.099) common carp (Poleksić et al., 2014, Rašković et al., 2016). The significant differences between the $\mathrm{N} / \mathrm{C}$ ratios resulted mainly from the size of hepatocyte nuclei which in our study were nearly two times greater in comparison with those reported earlier
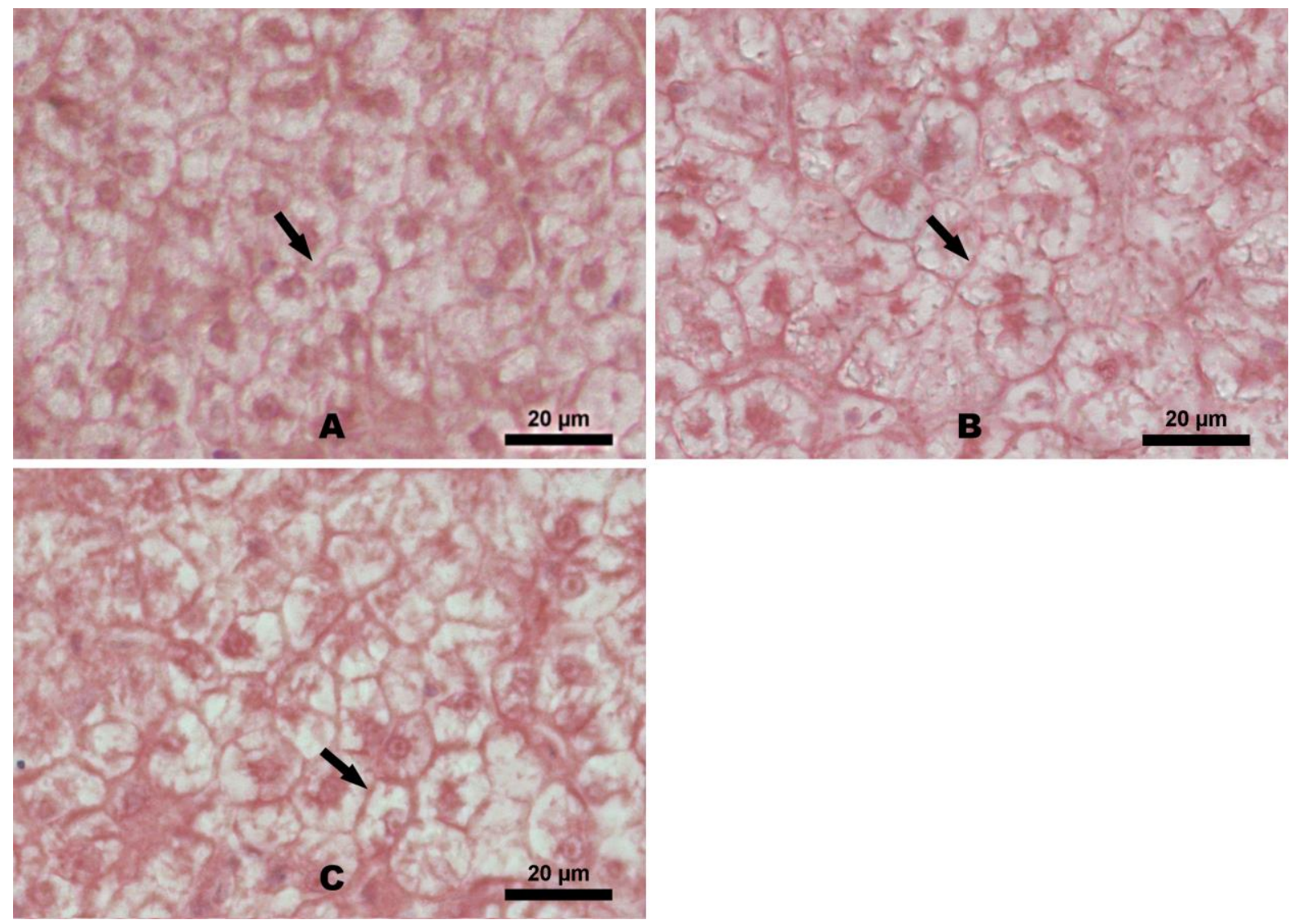

Figure 2. Carps liver histological images of all examined diets $A-C$ at the end of feeding trail ( $t=61$ days). Minor percentage of hepatocytes with periphery placed nucleus were found in carps under all diets (arrows). 
for adult and juvenile carps. Moreover, the morphometric assessment of hepatocytes revealed that in all analysed groups, a small number of peripherally displaced nuclei were observed. According to Caballero et al. (1999, and references therein), enlarged nuclei of hepatocytes and nuclear displacement to the hepatocyte periphery, depending on the experimental conditions, are considered as a pathological situation or might be regarded as an adaptive mechanism of hepatocytes. In the presented study, the morphology of hepatocytes was similar between the analysed carp diets. Therefore, the observed hepatic morphology reflected a well-fed status rather than a pathological situation. Microscopic examination of the gut mucosa revealed that the length of the intestinal folds was affected by farming conditions and, in our opinion, mainly by the ingested feeds. The length of the folds increased with decreasing level of fat in the diet, and this is comparable with previous results obtained for carp (Poleksić et al., 2014). Although the authors did not assess the structure of natural food present in fish ponds, and especially the level of lipids, the results obtained by Vacha et al. (2007), Bogut et al. (2010) and Ljubojević et al. (2017, and references therein) confirmed a low $(0.1-0.8 \%)$ and highly variable level of fat in the natural diet of carp, especially during midsummer. The different histomorphology of the intestine folds in diet $\mathrm{C}$ might be related to the low durability of

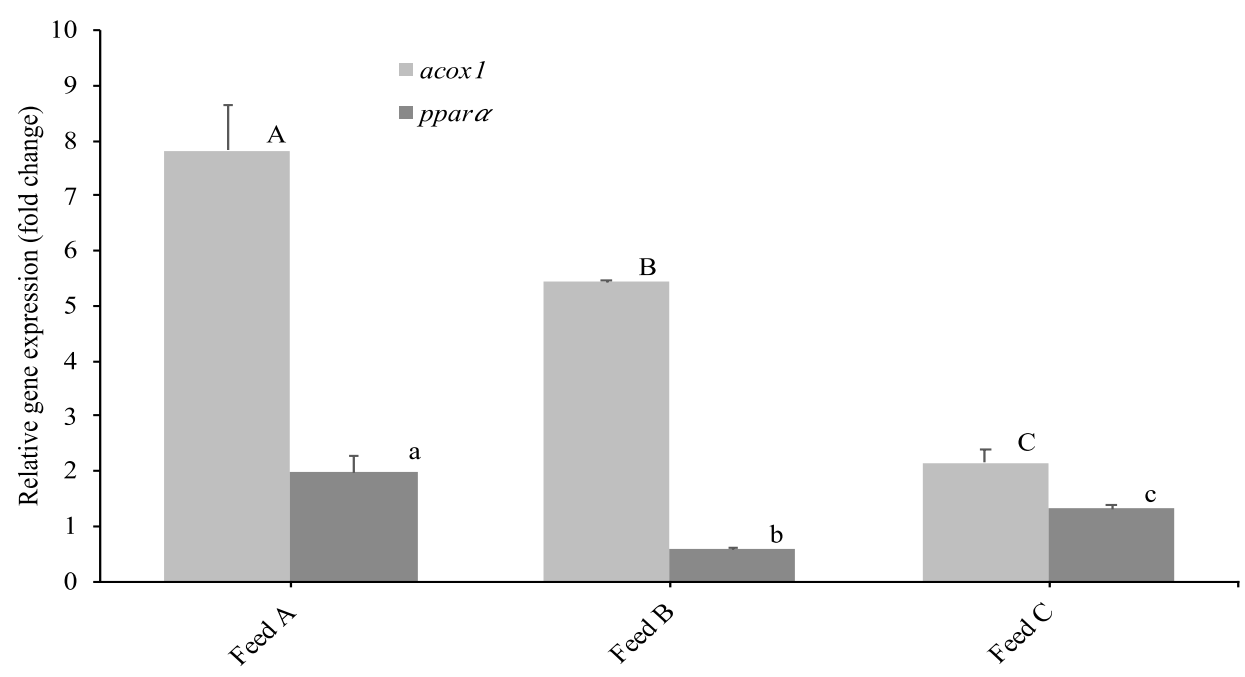

Figure 3. Relative gene expressions of lipid-related genes in liver. The values of the expression of the target genes are presented as relative to samples before trial. Mean values and standard error ( \pm S.E.M. $)$ are present for each parameter $(n=9$ fish per diet). Data were normalized by $r p / 8$. Means with various superscript letters are significantly different $(P \leq 0.05)$. ppar $\alpha$ : peroxisome proliferator-activated receptor alpha; acox1: acyl-CoA oxidase.

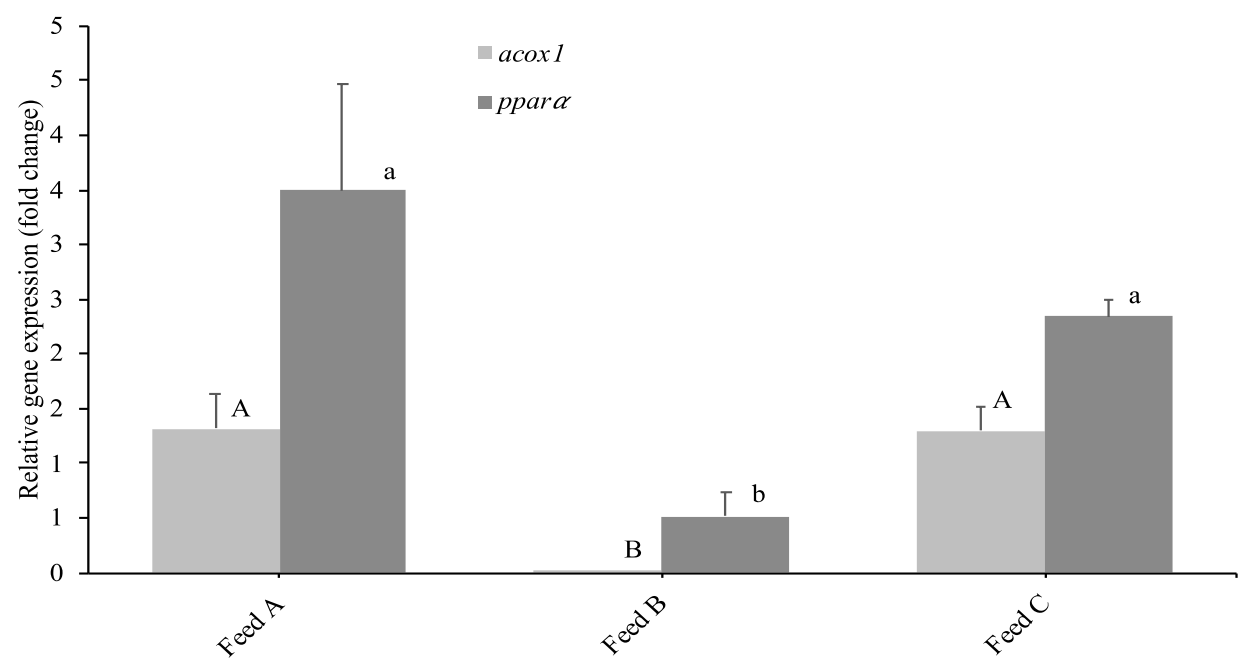

Figure 4. Relative gene expressions of lipid-related genes in intestine. The values of the expression of the target genes are presented as relative to samples before trial. Mean values and standard error ( \pm S.E.M.) are present for each parameter $(n=9$ fish per diet). Data were normalized by $r p / 8$. Means with various superscript letters are significantly different $(P \leq 0.05)$. ppar $\alpha$ : peroxisome proliferator-activated receptor alpha; acox1: acyl-CoA oxidase. 
the textured (non-pelleted) feed which had a high degree of disintegration just after administration. An additional explanation for that observation might be related to a somewhat limiting influence of one of the ingredients in feed C. Additionally, the presented study showed that the number of goblet cells was the lowest in the diet A fish, which apparently had the highest protein/lipid ratio $(0.31)$ compared with diets $B(0.20)$ and $C(0.16)$. The plausible explanation is that in experimental conditions, well-fed fish reduce the number of goblet cells, whereas starved fish increase this number along with the elongation of the intestinal folds, as was evidenced for rainbow trout by Berillis et al. (2017), and for Asian seabass (Lates calcarifer) by Purushothaman et al. (2016). However, no apparent effect on the number of goblet cells could be observed in other dietary treatments. Additionally, the significant difference in the size of goblet cells is difficult to explain. According to Berillis et al. (2017), the size of goblet cells decreased $6 \mathrm{~h}$ after feeding and regained their original size $12 \mathrm{~h}$ after feeding. In our study, this could not be the possible cause of the observed differences, because fish were starved equally. However, lower durability of feed $C$ could potentially extend fasting period. Further trials are necessary to clarify the effect of dietary treatments on the abundance and histomorphology of goblet cells.

The observed changes in the liver metabolism of carps fed with the experimental diets were additionally reflected by the significant differences in the activity of the two main genes responsible for fatty acid catabolism: acox1 and ppar $\alpha$. The different expression of acox 1 in the livers of carps fed with the three diets suggests that feeds were able to influence the hepatic fatty acid oxidation capacity. This is particularly due to the elevated contents of saturated and monounsaturated fatty acids in the diets, mainly 18:1n9 (oleic acid). Nutritional studies with Atlantic salmon have shown that various levels of $18: 1 n-9$ in feed significantly alter the expression of genes responsible for fatty acid oxidation in the liver (Bell et al., 2003). In a study by Stubhaug et al. (2005), an increased $\beta$ oxidation capacity in liver was also found when fish were fed diets containing high levels of fish or vegetable oils. Our study also showed that feeding common carp with diets containing a high level of fat did not reduce the activity of acox1, as it has been observed for mammals (Ringseis \& Eder, 2011). Therefore, this study revealed that the acox 1 gene co-maintaining $\beta$-oxidation in peroxisomes is regulated differently and, possibly, the up-regulation might confirm positive correlations between genes controlling both the fatty acid synthesis and $\beta$-oxidation pathways, as it has been evidenced for Atlantic salmon (Torstensen et al., 2009) and barramundi, Lates calcarifer (Araújo et al., 2017). By contrast, the activity of this gene was significantly downregulated in blunt snout bream fed a high-fat diet (15\% fat), and large fat droplets in hepatocytes were present as compared with a group fed with a low-fat diet (5\%) (Lu et al., 2014). Hence, in our study, hepatocytes with a normal structure observed in all groups and the positive fat-dependent activity of the acox 1 gene indicate that common carp could ingest feeds with a higher level of fat, since no impairment in the hepatic $\beta$-oxidation capacity occurred. This hypothesis appears satisfactory because the expression of ppar $\alpha$ in the liver of carps fed the high-fat diet A (9.90\%) was significantly higher than that in the fish fed diets B (6.5\%) and C (5\%) with lower fat levels. The elevated gene expression of acox 1 and ppar $\alpha$ in the diet A fish indicates intensified fatty acid uptake and transport, which correlates with the increased lipid accumulation in the fillet but not in hepatocytes in the form of fat droplets. Further evidence is that fat intake far exceeding the demand leads to blockings of the triglyceride transport and fatty acid oxidation, cellular and tissue damage, as well as dysfunction and inhibition of the PPAR $\alpha$ expression, as evidenced by Choi and Ginsberg (2011). The activity of ppar $\alpha$ and its target gene acox 1 in the intestine of fish showed a distinct pattern in relation to liver samples, since feeds with high and low levels of fat exerted a comparable effect on the mRNA levels of the studied genes. The difference in the activity of the genes between the liver and the intestine may result from a significantly lower expression of ppar $\alpha$ in the latter tissue, as has been shown for adult individuals of blunt snout bream, a species closely related to common carp (Zhao et al., 2011, Wang et al., 2017). The most plausible explanation might be that not the intestine, but peroxisomes, mitochondria and microsomes in the liver are the main place for energy storage and supply in fish in which PPAR $\alpha$ plays a pivotal role in lipid metabolism. Furthermore, Yang et al. (2017) revealed that the mRNA expression of ppar $\alpha$ in the liver significantly increased with the dietary lipid levels in comparison with other tissues of redlip mullet (Liza haematocheila). This finding indirectly confirms that feeds with high and low levels of fat used in carps exerted a similar effect on the activity of ppar $\alpha$ and its target gene acox 1 in the intestine. Moreover, down-regulation of the genes in the carp fed on feed B shows that this complex physiological process has not yet been wellcharacterised, and further studies should be conducted to elucidate the core mechanism by which dietary fat affects the ppar $\alpha$ and acox 1 expression in common carp.

\section{Conclusions}

In conclusion, this study showed that the level of fat in common carp diets correlated with the level of lipids in the meat, affected selected histomorphometric parameters of the liver and the intestine, and had a profound impact on the activity of ppar $\alpha$ and its target gene acox 1 in the liver. Additionally, our study revealed that feed A with the highest content of fat (9.90\%) positively affected the carp growth rate and did not exert negative effects on the liver and intestine 
histomorphology. Furthermore, the analysed genes (mostly acox1) in the liver responded in a leveldependent manner according to the content of fat in the ingested feeds. Overall, the feeding trial demonstrated that monitoring of histomorphological parameters and gene activities represents a useful tool in monitoring the health, quality and performance of common carp challenged within dietary treatments. Finally, the obtained results can provide theoretical guidance for future experiments with fishmeal replacements.

\section{Acknowledgements}

This study was funded by the Department of Meat Sciences and Department of Aquatic Bioengineering and Aquaculture of the West Pomeranian University of Technology (ZUT, Szczecin, Poland). All applicable international, national, and/or institutional guidelines for the care and use of animals were followed by the authors. We would like to thank Mr Marek Bartłomiejczyk for kindly maintaining cultured carps. We would like to thank the fish farmers from Maliniec pond farm who kindly helped in fish harvesting. The authors declare that there is no conflict of interest. The datasets generated during the current study are available from the corresponding author on a reasonable request.

\section{References}

Abasubong, K.P., Li, X-F., Zhang, D-D., Jia, E-T., Xiang-Yang, Y., Xu, C., \& Liu, W-B. (2018). Dietary supplementation of xylooligosaccharides benefits the growth performance and lipid metabolism of common carp (Cyprinus carpio) fed high-fat diets. Aquaculture Nutrition, 24(5), 14161424. https://doi.org/10.1111/anu.12678

Abbass, F. E. (2007). Effect of dietary oil sources and levels on growth, feed utilization and whole-body chemical composition of common carp, Cyprinus carpio L. fingerlings. Journal of Fish Aquatic Sciences, 2(2), 140148. https://doi.org/10.3923/jfas.2007.140.148

Anon. (2012). Guidelines for the treatment of animals in behavioural research and teaching. Animal Behaviour, 83(2012), 301-309. https://doi.org/10.1016/j.anbehav.2011.10.031

AOAC International. (2007). Official methods of analysis of AOAC International, AOAC International, Gaithersburg, $M D, A O A C$ International.

Araújo, B., Salini, M., Glencross, B., \& Wade, N. (2017). The influence of dietary fatty acid and fasting on the hepatic lipid metabolism of barramundi (Lates calcarifer). Aquaculture Research, 48(7), 3879-3893. https://doi.org/10.1111/are.13215

Aubin, J., Callier, M., Rey-Valette, H., Mathe, S., Wilfart, A., Legendre, M., Slembrouck, J., Caruso, D., Chia, E., Masson, G., Blancheton, J. P., Ediwarman, Haryadi, J., Prihadi T. H., Casaca, J. M., Tamassia S. T. J., Tocqueville, A., \& Fontaine, P. (2019). Implementing ecological intensification in fish farming: definition and principles from contrasting experiences. Reviews in Aquaculture, 11(1), 149-167. https://doi.org/10.1111/raq.12231

Bell, J. G., McGhee, F., Campbell, P. J., \& Sargent, J. R. (2003). Rapeseed oil as an alternative to marine fish oil in diets of post-smolt Atlantic salmon (Salmo salar): changes in flesh fatty acid composition and effectiveness of subsequent fish oil "wash out". Aquaculture, 218(1-4), 515-528.

https://doi.org/10.1016/S0044-8486(02)00462-3

Berillis, P., Martin, S., \& Mente, E. (2017). Histological methods to assess the effect of diet and a single meal on the liver and intestine of rainbow trout: fishmeal and fishoil replacement with plant protein and oil. In: P. Berillis (Eds.) Trends in Fisheries and Aquatic Animal Health (pp. 262-276). Sharjah, UAE, Bentham Science publishers. https://doi.org/10.2174/9781681085807117010014

Bickley, L. K., Lange, A., Winter, M. J., \& Tyler, C. R. (2009). Evaluation of a carp primary hepatocyte culture system for screening chemicals for oestrogenic activity. Aquatic Toxicology, 94(3), 195-203. https://doi.org/10.1016/j.aquatox.2009.07.006

Bogut, I., Adamek, Z., Puškadija, Z., \& Galović, D. (2010). Nutritional value of planktonic cladocera Daphnia magna for common carp (Cyprinus carpio) fry feeding. Croatian Journal of Fisheries: Ribarstvo, 68(1), 1-10. https://hrcak.srce.hr/50792

Burck, H. C. (1975). Utrwalanie. Technika histologiczna. [Fixation. Histological Technique.] Warsaw, Poland, PZWL, 62-63 pp. [In Polish]

Caballero, M. J., López-Calero, G., Socorro, J., Roo, F. J., Izquierdo, M. S., \& Férnandez, A. J. (1999). Combined effect of lipid level and fish meal quality on liver histology of gilthead seabream (Sparus aurata). Aquaculture, 179(1-4), 277-290. https://doi.org/10.1016/S00448486(99)00165-9

Cao, X. F., Liu, W. B., Zheng, X. C., Yuan, X. Y., Wang, C. C., \& Jiang, G. Z. (2018). Effects of high-fat diets on growth performance, endoplasmic reticulum stress and mitochondrial damage in blunt snout bream Megalobrama amblycephala. Aquaculture Nutrition, 25(1), 1-13. https://doi.org/10.1111/anu.12834

Choi, S. H., \& Ginsberg, H. N. (2011). Increased very low density lipoprotein (VLDL) secretion, hepatic steatosis, and insulin resistance. Trends in Endocrinology and Metabolism, 22(9), 353-363. https://doi.org/10.1016/j.tem.2011.04.007

Corcoran, J., Winter, M. J., Lange, A., Cumming, R., Owen, S. F., \& Tyler, C. R. (2015). Effects of the lipid regulating drug clofibric acid on PPAR $\alpha$-regulated gene transcript levels in common carp (Cyprinus carpio) at pharmacological and environmental exposure levels. Aquatic Toxicology, 161, 127-137. https://doi.org/10.1016/j.aquatox.2015.01.033

FAO. (2018). Fishery Statistical Collections. Global Aquaculture Production. Retrieved from http://www.fao.org/fishery/statistics/globalaquaculture-production/en. Accessed 10 July 2019.

Gao, W., Liu, Y. J., Tian, L. X., Mai, K. S., Liang, G. Y., Yang, H. J., Huai, M. Y., \& Luo, W. J. (2011). Protein-sparing capability of dietary lipid in herbivorous and omnivorous freshwater finfish: a comparative case study on grass carp (Ctenopharyngodon idella) and tilapia (Oreochromis niloticusx 0 . aureus). Aquaculture Nutrition, 17(1), 2-12. https://doi.org/10.1111/j.1365-2095.2009.00698.x

Hamilton, H. A., Newton, R., Auchterlonie, N. A., \& Müller, D. B. (2020). Systems approach to quantify the global omega-3 fatty acid cycle. Nature Food 1, 59-62. https://doi.org/10.1038/s43016-019-0006-0

Kiron, V., Phromkunthong, W., Huntley, M., Archibald, I., \& De 
Scheemaker, G. (2012). Marine microalgae from biorefinery as a potential feed protein source for Atlantic salmon, common carp and whiteleg shrimp. Aquaculture Nutrition, 18(5), 521-531. https://doi.org/10.1111/j.1365-2095.2011.00923.x

Król, E., Douglas, A., Tocher, D. R., Crampton, V. O., Speakman, J. R., Secombes, C. J., \& Martin, S. A. (2016). Differential responses of the gut transcriptome to plant protein diets in farmed Atlantic salmon. BMC genomics, 17(1), 156. https://doi.org/10.1186/s12864-016-2473-0

Lazzarotto, V., Médale, F., Larroquet, L., \& Corraze, G. (2018). Long-term dietary replacement of fishmeal and fish oil in diets for rainbow trout (Oncorhynchus mykiss): Effects on growth, whole body fatty acids and intestinal and hepatic gene expression. PLoS One, 13(1), e0190730. https://doi.org/10.1371/journal.pone.0190730

Ljubojević, D., Đorđević, V., \& Ćirković, M. (2017). Evaluation of nutritive quality of common carp, Cyprinus carpio L. IOP Conference Series: Earth Environmental Science, 85, 012013.

https://doi.org/10.1088/1755-1315/85/1/012013

Lu, K. L., Xu, W. N., Wang, L. N., Zhang, D. D., Zhang, C. N., \& Liu, W. B. (2014). Hepatic b-oxidation and regulation of carnitine palmitoyltransferase (CPT) I in Blunt Snout Bream Megalobrama amblycephala fed a high fat diet. PLoS One, 9(3), e93135.

https://doi.org/10.1371/journal.pone.0093135

Manjappa, K., Keshavanath, P., \& Gangadhara, B. (2002). Growth performance of common carp, Cyprinus carpio fed varying lipid levels through low protein diet, with a note on carcass composition and digestive enzyme activity. Acta Ichthyologica et Piscatoria, 32(2), 145-155. https://doi.org/10.3750/AIP2002.32.2.05

Muzaffar, A., Qureshi, T. A., Singh, A. B., Susan, M., Kamlesh, B., \& Chalko, S. R. (2012). Effect of dietary protein, lipid and carbohydrate contents on the growth, feed efficiency and carcass composition of Cyprinus carpio communis fingerlings. International Journal of Fisheries and Aquaculture, 4(3), 30-40.

https://doi.org/10.5897/IJFA11.080

Panicz, R., Żochowska-Kujawska, J., Sadowski, J., \& Sobczak, M. (2017). Effect of feeding various levels of poultry byproduct meal on the blood parameters, filet composition and structure of female tenches (Tinca tinca). Aquaculture Research, 48(10), 5373-5384. https://doi.org/10.1111/are.13351

Poleksić, V., Stanković, M., Marković, Z., Relić, R., Lakić, N., Dulić, Z., \& Rašković, B. (2014). Morphological and physiological evaluation of common carp (Cyprinus carpio L., 1758) fed extruded compound feeds containing different fat levels. Aquaculture International, 22(1), 289-298.

https://doi.org/10.1007/s10499-013-9654-5

Purushothaman, K., Lau, D., Saju, J. M., Musthaq, Sk. S., Lunny, D. P., Vij, S., \& Orbán, L. (2016). Morpho-histological characterisation of the alimentary canal of an important food fish, Asian seabass (Lates calcarifer). PeerJ, 4, e2377. https://doi.org/10.7717/peerj.2377

Rašković, B., Čičovački, S., Ćirić, M., Marković, Z., \& Poleksić, V. 2016. Integrative approach of histopathology and histomorphometry of common carp (Cyprinus carpio L.) organs as a marker of general fish health state in pond culture. Aquaculture Research 47(11), 3455-3463. https://doi.org/10.1111/are.12795

Ringseis, R., \& Eder, K. (2011). Regulation of genes involved in lipid metabolism by dietary oxidized fat. Molelular Nutrition \& Food Research, 55(1), 109-121. https://doi.org/10.1002/mnfr.201000424

Steffens, W. 1996. Protein sparing effect and nutritive significance of lipid supplementation in carp diets. Archives of Animal Nutrition, 49(1), 93-98. https://doi.org/10.1080/17450399609381867

Stubhaug, I., Tocher, D. R., Bell, J. G., Dick, J. R., \& Torstensen, B. E. (2005). Fatty acid metabolism in Atlantic salmon (Salmo salar L.) hepatocytes, and influence of dietary vegetable oil. Biochimica et Biophysica Acta (BBA) Molecular and Cell Biology of Lipids, 1734(3), 277-288. https://doi.org/10.1016/j.bbalip.2005.04.003

Torstensen, B. E., Nanton, D., Olsvik, P. A., Sundvold, H., \& Stubhaug, I. (2009). Gene expression of fatty acid binding proteins (FABPs), fatty acid transport proteins (cd36 and FATP) and b-oxidation related genes in Atlantic salmon (Salmo salar L.) fed fish oil or vegetableoil. Aquaculture Nutrition, 15(4), 440-445. https://doi.org/10.1111/j.1365-2095.2008.00609.x

Turchini, G. M., Hermon, K. M., \& Francis, D. S. (2018). Fatty acids and beyond: Fillet nutritional characterisation of rainbow trout (Oncorhynchus mykiss) fed different dietary oil sources. Aquaculture, 491, 391-397. https://doi.org/10.1016/j.aquaculture.2017.11.056

Vacha, F., Vejsada, P., Huda, J., \& Hartvich, P. (2007). Influence of supplemental cereal feeding on the content and structure of fatty acids during long-lasting storage of common carp (Cyprinus carpio L.). Aquaculture International, 15(3-4), 321-329.

https://doi.org/10.1007/s10499-007-9081-6

Wang, B. K., Liu, W. B., Xu, C., Cao, X. F., Zhong, X. Q., Shi, H. J., $\&$ Li, X. F. (2017). Dietary carbohydrate levels and lipid sources modulate the growth performance, fatty acid profiles and intermediary metabolism of blunt snout bream Megalobrama amblycephala in an interactive pattern. Aquaculture, 481, 140-153.

https://doi.org/10.1016/j.aquaculture.2017.08.034

Xu, P., Zhang, X., Wang, X., Li, J., Liu, G., Kuang, Y., Xu, J., Zheng, X., Ren, L., Wang, G., Zhang, Y., Huo, L., Zhao, Z., Cao, D., Lu, C., Li, C., Zhou, Y., Liu, Z., Fan, Z., ... Sun, X. (2014). Genome sequence and genetic diversity of the common carp, Cyprinus carpio. Nature Genetics, 46, 1212-1219. https://doi.org/10.1038/ng.3098

Yamada, K. (1970). An acriflavine alcian blue technique for dual staining of cartilage and mast cells in paraffin sections. Acta Histochemica et Cytochemica, 3(1), 1-6. https://doi.org/10.1267/ahc.3.1

Yang, W., Wang, A., Liu, F., Yu, Y., Qiao, G., Nie, Q., Lv, F., \& Lv, L. (2017). Peroxisome Proliferator-Activated Receptor Alpha (PPAR $\alpha$ ) in Redlip Mullet, Liza haematocheila: Molecular Cloning, mRNA Tissue Expression, and Response to Dietary Lipid Levels. Turkish Journal of Fisheries and Aquatic Sciences, 17(4), 689-699. https://doi.org/10.4194/1303-2712-v17_4_05

Zhao, Y., Gul, Y., Li, S., \& Wang, W. (2011). Cloning, identification and accurate normalization expression analysis of PPAR $\alpha$ gene by GeNorm in Megalobrama amblycephala. Fish \& Shellfish Immunology, 31(3), 462468. https://doi.org/10.1016/j.fsi.2011.06.024 